Www.jmscr.igmpublication.org

Impact Factor (SJIF): 6.379

Index Copernicus Value: 79.54

ISSN (e)-2347-176x ISSN (p) 2455-0450

crossrefDOI: https://dx.doi.org/10.18535/jmscr/v6i11.17

Journal Of Medical Science And Clinical Research

IGM Publication

An Official Publication of IGM Publication

Original Research Article

\title{
Effects of Nasal Suction on Outcome of Bronchiolitis
}

\author{
Authors \\ Dr Karan Joshi M.D, Dr Akhilendra Singh Parihar M.B.B.S, M.D, \\ Dr Jyoti Singh M.D. FIAP, Professor and Head, Dr Naresh Bajaj M.D \\ Department of Paediatrics, Shyam Shah Medical College, Rewa, Madhya Pradesh. \\ Corresponding Author
}

Dr Akhilendra Singh Parihar

Plot number- D/4 Aadarsh Cooperative Society, Behind Sai Dhaam, Sagra, Jabalpur (M.P) Pin 482003 India

Phone: 7879493657, Email: akhilendraparihar007@ gmail.com

\section{Abstract}

Objective: To study the effects of nasal suction on infants with bronchiolitis

Design: Prospective randomized control study

Setting: Department of paediatrics Shyam Shah Medical College and Gandhi Memorial Hospital, Rewa (MP)

Participants: 75 patients in study group and 75 patients in control group.

Main Outcome Measure(s): Length of hospital stay and change in acute bronchiolitis severity score in infants with bronchiolitis.

Results: The overall length of hospital stay in the patients suffering from bronchiolitis was $136.1 \pm 38.7$

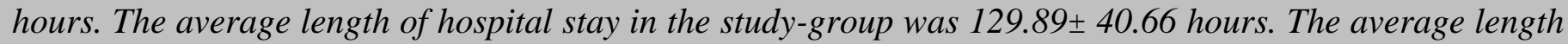
of hospital stay in the control-group was 142.31 35.84 hours. There was a significant decrease in the respiratory rate after two nasal suction episodes onwards in the infants. Feeding also showed significant improvement after $2^{\text {nd }}$ nasal suction episode. There was a significant decrease in the Acute Bronchiolitis Severity Score in study group.

Conclusions: Nasal suction is an effective supportive treatment in the patients with bronchiolitis and by using timely nasal suction length of hospital stay can be reduced. Nasal suction also decreases work of breathing and acute bronchiolitis severity score. It also improves the feeding. This non-invasive, simple procedure can be used in the community to decrease the burden of hospitalization on the family as well as on health care system.

Keywords: Bronchiolitis, Nasal suction, Acute Bronchiolitis Severity Score, Length of hospital stay.

\section{Introduction}

Bronchiolitis is the most common disease of the lower respiratory tract during the first year of life $^{(1)}$. American Academy of Pediatrics subcommittee defines bronchiolitis as "a disorder most commonly caused in infants by viral LRTI; it is the most common lower respiratory infection in this age group and is characterized by acute inflammation, edema and necrosis of epithelial cells lining small airways, increased mucus production and bronchospasm"(2). Smoking, overcrowding and low socioeconomic status are 
all associated with increased incidence of bronchiolitis related hospital admissions ${ }^{(3)}$. Infants with co-morbidities including premature birth, immunodeficiency, left to right shunt congenital heart disease or interstitial lung diseases are more prone to develop severe disease ${ }^{(4)}$. The diagnosis of bronchiolitis is clinical and is based on history and physical findings ${ }^{(5)}$. Although bronchiolitis is a prevalent illness in India, very few studies are performed in India regarding management of bronchiolitis. Supportive care is the mainstay of treatment concentrating on fluid replacement and gentle suctioning of nasal secretions, oxygen therapy, and respiratory support if necessary. Most of the hospitals and paediatricians use nasal suction as a mode of supportive therapy in bronchiolitis, but no study is available to document the effectiveness of nasal suction in the management of infants with bronchiolitis.

\section{Methodology}

This study was a prospective randomized control study, conducted at the department of Pediatrics Shyam Shah Medical College and Gandhi Memorial Hospital Rewa from January 2016 to March 2017 over a period of 15 months. Ethical clearance was obtained from institutional ethics committee. The study was conducted after determining strict inclusion and exclusion criteria.

\section{Inclusion Criteria}

- Patient diagnosed with bronchiolitis by attending pediatrician

- Age $<2$ years

- First episode of respiratory illness

- Symptoms associated with increased work of breathing \& lower respiratory tract symptoms that may include: increased work of breathing, persistent cough, feeding difficulty, rapid shallow respiration, +/- fever,+/- wheeze

\section{Exclusion Criteria}

- Cardiac disease requiring baseline medication

- History of recurrent respiratory illness

- Anatomic airway defect
- Neurologic disease

- Immunodeficiency (thrush, long term steroids, measles, patient on ART)

- Chronic lung disease or other significant lung diseases.

- Patients diagnosed with severe acute malnutrition or moderate acute malnutrition.

- Patients who were diagnosed as bronchopneumonia during the study were also excluded from the study.

- Patients in control arm in whom nasal suction was performed due to any reason.

A structured Proforma was filled for every child enrolled in the study. The parents of children of both study group and control group were informed about the purpose of research, and proper consent was taken. In this study total, 227 patients were enrolled. Out of these patients, 108 patients were in the control group and remaining 119 patients were classified under the study group. During the study, 33 patients from the control group and 44 patients from the study group dropped out; some due to change in their diagnosis, patients discharged before the fulfilment of discharge criteria and in some cases consent not given by their parents for study. So this study was conducted on 150 patients in total, out of which 75 were in control group and 75 were in the study group (figure-1). The diagnosis of Bronchiolitis was made by attending paediatrician which was based on the guidelines given by the American Academy of Pediatrics which includes children up to 2 years of age with the first episode of multitrigger wheeze. The patients were selected from those admitted in the department of Pediatrics G.M.H Rewa with the provisional diagnosis of Bronchiolitis every day by 7 P.M. By using a table of random numbers patients were divided into study group and control group. In control group, all the treatment remained same as was followed previously at our institute. But in the study group, we performed nasal suction, in addition to the treatment which was already given to control group. Nasal suction was carried out as soon as 
the patients were included in the study. The interval between 2 suction episodes was 4 hours and was performed till patient was discharged from the hospital. Mucus extractor was used for performing nasal suction. Suction was performed 30 seconds after putting 2 drops of normal saline in each nostril. The patient's end of mucus extractor was inserted 2- 3 c.m inside the nasal cavity from nostrils. Suction was performed under observation of pediatrician, but patient's attendants were also trained for performing suction. We used acute bronchiolitis severity score (table 1) given by Fernández et al ${ }^{(6)}$ to measure the severity of bronchiolitis in our patients objectively.

This score was observed every 4 hourly in the control group and in study group score was observed before performing nasal suction and after the nasal suction. The patients were monitored and followed till the time they fulfilled the criteria for discharge which are as follows:

- No retractions : subcostal, intercostal, suprasternal, and supraclavicular

- Average respiratory rate for last 24 hours : 0-2 months $-\leq 60 / \mathrm{min}$

2-12 months- $\leq 50 / \mathrm{min}$

$12-24$ months $-\leq 40 / \mathrm{min}$

- $\mathrm{SPO}_{2}$ at room air for last 24 hours at quiet awake state : $\geq 95 \%$

- Not receiving Intra Venous Fluids.

- Taking adequate oral intake which is about $75 \%$ of patient's usual intake.

\section{Statistical Analysis}

Data were entered using Microsoft ${ }^{\circledR}$ Excel 2010 and data was analysed using Microsoft ${ }^{\circledR}$ Excel 2010 and GraphPadInstat@, for the statistical analysis we used paired t-test, unpaired t-test, and chi-square test.

\section{Results}

In our study, $73 \%$ patients were males and all the patients diagnosed with bronchiolitis were less than 12 months of age, with a mean age of $4.61 \pm$ 3.01 months and the median age of 4 months.
Most of the patients were of age group 2 months to 6 months (44\%). Rapid breathing was present in all the patients followed by runny nose68\% $(n=102)$. Cough was present in $67 \% \quad(n=101)$ children, fever was present in $57 \%(n=85)$ of infant and most of the time it was of mild grade in intensity, $48 \%$ children presented with refusal to feed (table-2).

The average ABSS before nasal suction at 0 hours was $8.88 \pm 2.48$ and after nasal suction at 0 hours was $7.69 \pm 2.48$. Similar results were obtained at the 4th hour, 8th hour, 12th hour, 16th hour, 20th hour where p-value was $<0.0001$ which is extremely significant and at the 24th hour where $\mathrm{p}$ value was $<0.002$ which is highly significant (table-3).

After the first episode of nasal suction at hour 0 feeding difficulty persisted in most of the patients (p-value 0.1148 not significant). But from 4th hour till the 16th hour continuous improvement in feeding was observed after the nasal suction, and by Chi-square test this improvement was statistically significant. From 20th hour difficulty in feeding still improved after nasal suction but this change was not statistically significant (figure-2).

In our study the overall length of hospital stay in the patients suffering from bronchiolitis was $136.1 \pm 38.7$ hours. The average length of hospital stay in the study-group was $129.89 \pm 40.66$ hours and in the control group was $142.31 \pm 35.84$ hours p-value $<0.0492$ which was statistically significant (table-4). 
Table-1 Acute Bronchiolitis Severity Score Tool

\begin{tabular}{|c|c|c|c|c|c|}
\hline POINT & 0 & 1 & 2 & 3 & 4 \\
\hline WHEEZING & No & $\begin{array}{l}\text { At the end } \\
\text { of expiration }\end{array}$ & $\begin{array}{l}\text { Throughout } \\
\text { expiration }\end{array}$ & $\begin{array}{l}\text { Inspiration and } \\
\text { expiration both }\end{array}$ & Hypoventilation \\
\hline CRACKLES & No & In 1 field & In 2 fields & In 3 fields & In 4 fields \\
\hline EFFORTS & No effort & $\begin{array}{c}\text { Subcostal or } \\
\text { lower } \\
\text { intercostal }\end{array}$ & $\begin{array}{l}\text { Subcostal or } \\
\text { lower } \\
\text { intercostal }+ \\
\text { retraction or } \\
\text { nasal flaring }\end{array}$ & $\begin{array}{l}\text { Subcostal or lower } \\
\text { intercostal }+ \\
\text { retraction }+ \text { nasal } \\
\text { flaring + suprasternal } \\
\text { (universal) }\end{array}$ & \\
\hline $\begin{array}{l}\text { INSPIRATION/EXPIRATIO } \\
\text { N TIME RATIO }\end{array}$ & $\mathrm{I}>\mathrm{E}$ & $\mathrm{I}=\mathrm{E}$ & $\mathrm{I}<\mathrm{E}$ & & \\
\hline RESPIRATORY RATE & & & & & \\
\hline $\begin{array}{l}<2 \text { MONTHS } \\
2-6 \text { MONTHS } \\
6-12 \text { MONTHS }\end{array}$ & $\begin{array}{l}<57 \\
<53 \\
<47\end{array}$ & $\begin{array}{l}57-66 \\
53-62 \\
47-55\end{array}$ & $\begin{array}{l}>66 \\
>62 \\
>55\end{array}$ & & \\
\hline $\begin{array}{l}\text { HEART RATE } \\
7 \text { DAYS-2 MONTHS } \\
2-12 \text { MONTHS }\end{array}$ & $\begin{array}{l}125-152 \\
120-140\end{array}$ & $\begin{array}{l}153-180 \\
140-160\end{array}$ & $\begin{array}{l}>180 \\
>160\end{array}$ & & \\
\hline
\end{tabular}

\section{Interpretation}

0-4 Mild

5-9 Moderate

10-17 Severe

*With authors permission

Fernández JR, Martínez AC, Zavala RG, Cardona AU. Validación de unaescalaclínica de severidad de la bronquiolitisaguda.InAnales de pediatría 2014 Jul 31 (Vol. 81, No. 1, pp. 3-8). Elsevier Doyma.

Table- 2 Distribution of Patients

\begin{tabular}{|l|c|c|}
\hline Characteristics & Frequency & Percentage \\
\hline 1. Gender & & \\
\hline Female & 109 & 72.67 \\
\hline \multicolumn{1}{|c|}{ Age } & 41 & 27.33 \\
\hline 0-2 Months & & \\
\hline 2-6 Months & 51 & 34 \\
\hline 6-12 Months & 66 & 44 \\
\hline & 33 & 22 \\
\hline 3.Presenting Complaint & & \\
\hline & & \\
\hline Fever & 85 & 56.67 \\
\hline Cough & 101 & 67.33 \\
\hline Cold (runny nose) & 102 & 68 \\
\hline Rapid breathing & 150 & 100 \\
\hline Refusal to feed & 72 & 48 \\
\hline
\end{tabular}


Table- 3 Comparison of Acute Bronchiolitis Severity Score before and after nasal suction

\begin{tabular}{|c|c|c|c|c|}
\hline Time (at hour) & $\begin{array}{l}\text { Acute Bronchiolitis } \\
\text { Severity Score }\end{array}$ & Mean & SD & P-value \\
\hline \multirow[t]{2}{*}{$0^{\text {th }}$} & Before nasal suction & 8.88 & 2.48 & \multirow[t]{2}{*}{$<0.0001$} \\
\hline & After nasal suction & 7.69 & 2.48 & \\
\hline \multirow[t]{2}{*}{$4^{\text {th }}$} & Before nasal suction & 8.13 & 2.58 & \multirow[t]{2}{*}{$<0.0001$} \\
\hline & After nasal suction & 7.32 & 2.48 & \\
\hline \multirow[t]{2}{*}{$8^{\text {th }}$} & Before nasal suction & 7.29 & 2.74 & \multirow[t]{2}{*}{$<0.0001$} \\
\hline & After nasal suction & 6.72 & 2.58 & \\
\hline \multirow[t]{2}{*}{$12^{\text {th }}$} & Before nasal suction & 6.48 & 2.64 & \multirow[t]{2}{*}{$<0.0001$} \\
\hline & After nasal suction & 5.89 & 2.51 & \\
\hline \multirow[t]{2}{*}{$16^{\text {th }}$} & Before nasal suction & 5.63 & 2.73 & \multirow[t]{2}{*}{$<0.0001$} \\
\hline & After nasal suction & 5.12 & 2.43 & \\
\hline \multirow[t]{2}{*}{$20^{\text {th }}$} & Before nasal suction & 4.63 & 2.53 & \multirow[t]{2}{*}{$<0.0001$} \\
\hline & After nasal suction & 4.29 & 2.41 & \\
\hline \multirow[t]{2}{*}{$24^{\text {th }}$} & Before nasal suction & 3.73 & 2.38 & \multirow[t]{2}{*}{0.0022} \\
\hline & After nasal suction & 3.57 & 2.23 & \\
\hline
\end{tabular}

Table 4: Comparison of Length of stay between Study group and Control group

\begin{tabular}{|l|c|c|c|c|}
\hline $\begin{array}{l}\text { Age group } \\
\text { (Months) }\end{array}$ & Group & Mean(hours) & SD(hours) & P-value \\
\hline & & & & \\
\hline $0-2$ & Control group & 143.68 & 32.15 & 0.3295 \\
\cline { 2 - 4 } & Study group & 133.61 & 40.88 & \\
\hline $2-6$ & Control group & 138.57 & 43.18 & \multirow{2}{*}{0.3984} \\
\cline { 2 - 4 } & Study group & 129.39 & 44.06 & \\
\hline $6-12$ & Control group & 146.64 & 27.69 & \multirow{2}{*}{0.0593} \\
\cline { 2 - 4 } & Study group & 125.69 & 33.67 & \\
\hline \multirow{2}{*}{ overall } & Control group & 142.31 & 35.84 & \multirow{2}{*}{0.0492} \\
\cline { 2 - 4 } & Study group & 129.89 & 40.66 & \\
\hline
\end{tabular}

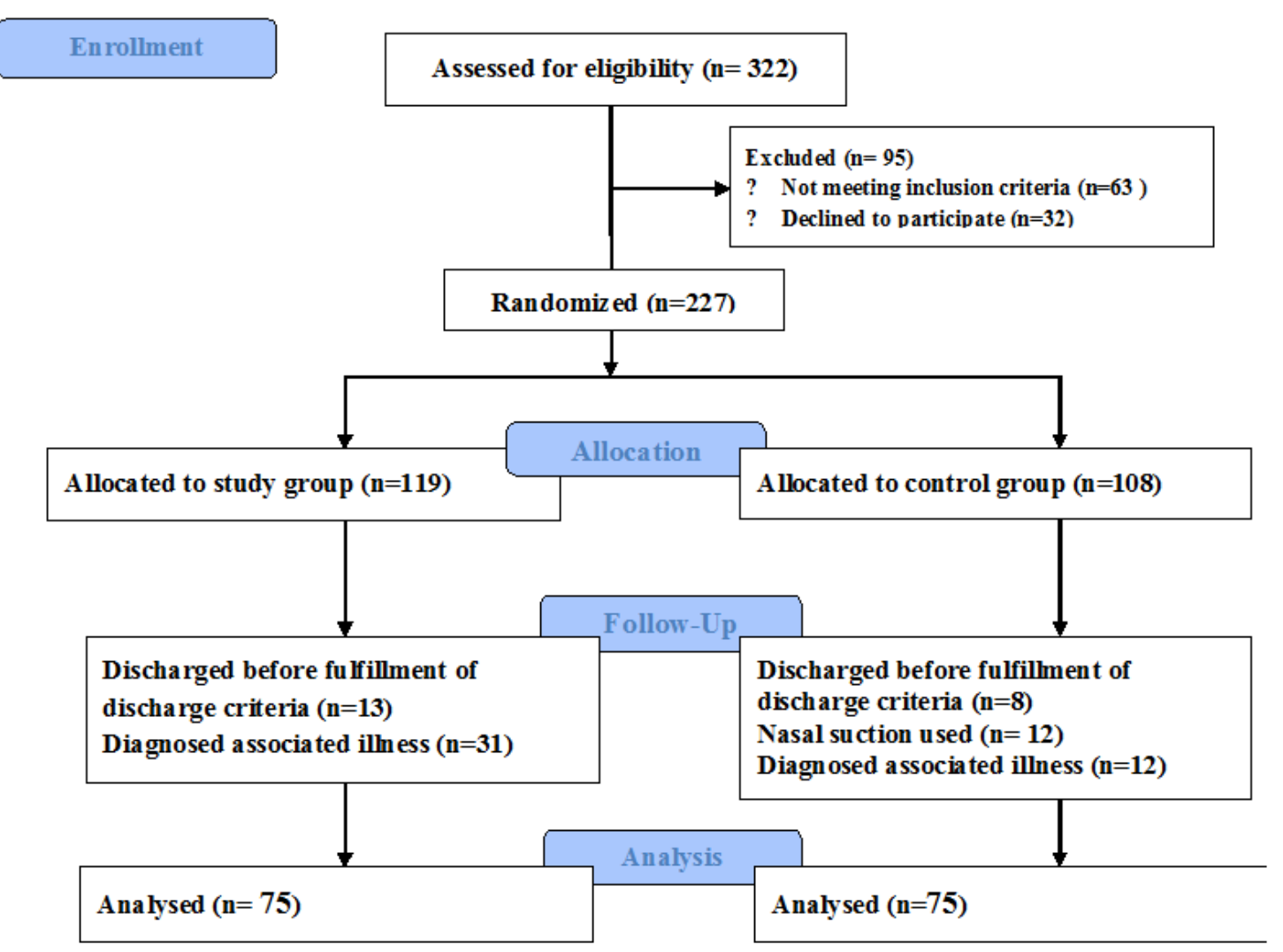

Figure- 1 Consort Flow diagram 
- Feeding Difficulty Present $\quad$ Feeding difficulty absent

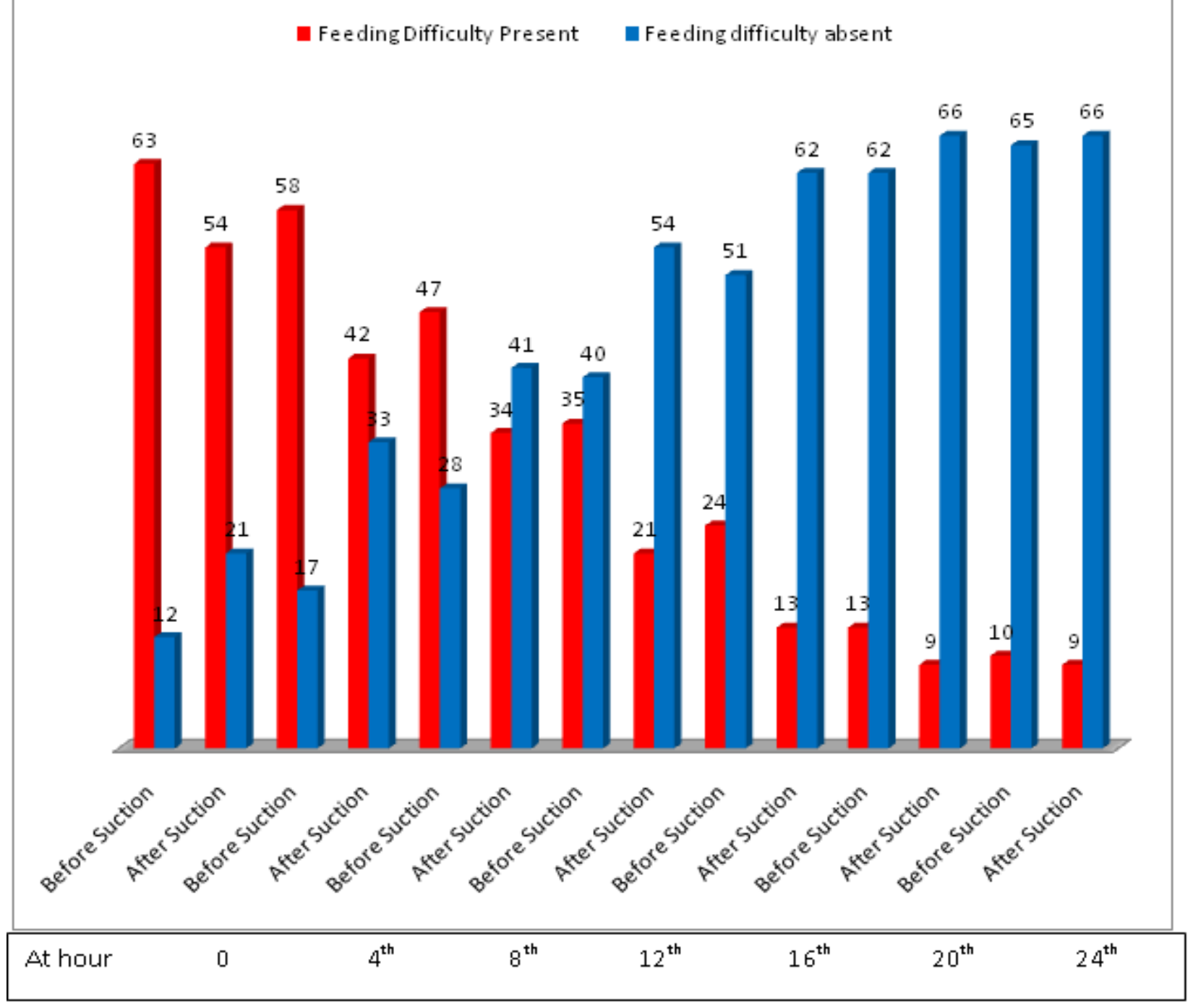

Figure-2 Comparison of feeding difficulty before and after nasal suction

\section{Discussion}

Bronchiolitis mostly affects infants which is also reflected in our study where all the children affected by bronchiolitis were less than 12 months old. We have $78 \%$ patients who were up to 6 months old.In a prospective hospital-based study from Southern India, of 114 children with bronchiolitis, $87(76 \%)$ were less than 1 year, and $107(94 \%)$ were less than 2 years of age ${ }^{(7)}$. We found that there is a significant decrease in the Acute Bronchiolitis Severity Score after the nasal suction. The reason behind this could be that nasal suction clears the secretion from upper respiratory airway which increases the air flow in the respiratory tract which can be observed in the form of decreased respiratory effort and decreased expiratory time. We also observed that after starting nasal suction there is alleviation in feeding difficulty in the study group as compared to control group. This effect starts after 2 suction episodes but after some time this change does not remain statistically significant. This can be due to the reason that bronchiolitis is a self-limiting illness and patient starts improving after supportive care so initially nasal suction significantly decrease feeding difficulties. So nasal suction is helpful in the initial phase of illness as an aid to improve feeding, and by this, it also helps in improving hydration status of the infant.

In the study, the average length of hospital stay decreased after nasal suction in patients with bronchiolitis. The Overall average length of stay was $136.1 \pm 38.7$ hours. In a recent cross-sectional study of Tamilnadu, the average length of hospital stay is 5-6 days ${ }^{(8)}$. 
We only suctioned nasal cavity in our study that clears the nasal cavity from secretions and impacted mucous and provides relief from the nasal obstruction which leads to the improved air movement in lower airways and thus increases mobilization of secretions, which results in decreased recovery time. It is also possible that regular suctioning results in the agitation of the patient, with resultant increase in minute volume and secretion mobilization.

\section{Conclusion}

By this study, we can conclude that nasal suction is an effective supportive treatment in the patients with bronchiolitis and by its use length of hospital stay in patients with bronchiolitis can be decreased. It also decreases work of breathing which is manifested in the overall decrease in acute bronchiolitis severity score. Nasal suction also improves the feeding in the infants suffering from bronchiolitis. In patients with bronchiolitis nasal suction should be used as a supportive therapy because of its documented benefit in decreasing length of hospital stay and its effectiveness in alleviating obnoxious symptoms. We recommend the use of nasal suction at the community level because it is an easy to teach, easy to learn, economical, and nonpharmacological therapy, and it can also be performed at home. It can help in decreasing the burden of disease on family and healthcare facilities.

WHAT IS ALREADY KNOWN?
Nasal suction is a recommended supportive
therapy in bronchiolitis but there is no study
which signifies the effects of nasal suction in
patients with bronchiolitis.
WHAT THIS STUDY ADDS?
The study proves the benefits of nasal suction in
patients with bronchiolitis in terms of alleviating
feeding difficulties in infants with bronchiolitis,
and also reducing the length of hospital stay. It
can be recommended as a home-based
supportive care in infants with bronchiolitis.

Source (s) of support in the form of grants, equipment, drugs or all of these - nil

Declaration on competing interests - nil

\section{Reference}

1. Wright AL, Taussig LM, Ray CG, Harrison HR, Holberg CJ, GROUP HEALTH MEDICAL ASSOCIATES. The Tucson Children's Respiratory Study: II. Lower respiratory tract illness in the first year of life. American journal of epidemiology. 1989 Jun 1;129(6):1232-46.

2. Diagnosis and management of bronchiolitis. Pediatrics 2006; 118:1774-93.

3. Spencer N, Logan S, Scholey S, Gentle S. Deprivation and bronchiolitis. Archives of disease in childhood. 1996 Jan 1;74(1):502.

4. Heikkinen $\mathrm{T}$, Valkonen $\mathrm{H}$, Lehtonen $\mathrm{L}$, Vainionpää R, Ruuskanen O. Hospital admission of high risk infants for respiratory syncytial virus infection: implications for palivizumab prophylaxis. Archives of Disease in Childhood-Fetal and Neonatal Edition. 2005 Jan 1;90(1):F64-8.

5. García CG, Bhore R, Soriano-Fallas A, Trost M, Chason R, Ramilo O, Mejias A. Risk factors in children hospitalized with RSV bronchiolitis versus non-RSV bronchiolitis. Pediatrics. 2010 Dec 1;126(6):e1453-60.

6. Fernández JR, Martínez AC, Zavala RG, Cardona AU. Validación de unaescalaclínica de severidad de la bronquiolitisaguda. InAnales de pediatría 2014 Jul 31 (Vol. 81, No. 1, pp. 3-8). Elsevier Doyma.

7. Cherian T, Simoes EA, Steinhoff MC, Chitra K, John M, Raghupathy P, John TJ. Bronchiolitis in tropical south India. American Journal of Diseases of Children. 1990 Sep 1;144(9):1026-30.

8. Joseph R, Vamshi G, Suresh K, Dhanapal C, Chidambaranathan S. Study of Nebulization with Hypertonic Saline and 
Other Nebulizing Agents with or With Out Antibiotics in Bronchiolitis Patients Aged 2 Months to 2 Years Admitted In RMMCH. IOSR Journal of Pharmacy and Biological Sciences. [Online] 2017; 12(4): 01-07. Available from: http://www.iosrjournals.org/iosrjpbs/papers/Vol12-issue4/Version4/A1204040107.pdf [Accessed 18 September 2017]. 